\title{
Fatty Acid and Alcohol Distributions and Sources in Surface Sediments of Imo River, Southeast Niger Delta, Nigeria
}

\author{
Orok E. Oyo-Ita ${ }^{1}$ \& Inyang O. Oyo-Ita ${ }^{1}$ \\ ${ }^{1}$ Department of Pure and Applied Chemistry, University of Calabar, Nigeria \\ Correspondence: Orok E. Oyo-Ita, Department of Pure and Applied Chemistry, University of Calabar, Nigeria. \\ E-mail: orokoyoita@yahoo.com
}

Received: July 23, 2012 Accepted: September 25, 2012 Online Published: October 30, 2012

doi:10.5539/enrr.v2n4p101 URL: http://dx.doi.org/10.5539/enrr.v2n4p101

\begin{abstract}
The distributions and concentrations of extractable fatty acids (FAs) and alcohols (FALs) in surface sediments of the Imo River were determined to estimate the relative proportion of terrigenous and autochthonous fractions of organic matter (OM) input to the river. The range of total organic carbon (TOC) content (2.10-4.58\%) is typical for coastal environments and comparable to those of other river systems within the Niger Delta region. This may be a reflection of the sheltered basin morphology and high energy conditions of the river, characterized by overwhelming sand fraction. The contribution from terrestrial vegetation appears to predominate the distribution of FAs (21.17-75.16\%) and alcohols (38.7-81.7\%), in contrast to many aquatic sediments whose distributions are either phytoplankton or bacteria dominated. This may be linked to the relatively shallow water depth, oxic and refractory nature of the sedimentary organic carbon of the area as well as proximity of most sampling points to terrigenous source. Utilization of ratios confirmed this pattern and indicated that the OM deposited at the time of sampling was not fresh. The dominance of 19:0 acids in some samples is associated to an input from a certain consortium of bacteria with a different physiological structure inhabiting petroleum contaminated environment.
\end{abstract}

Keywords: fatty acid, acyclic alcohol, distribution, sources and Imo river sediment

\section{Introduction}

Rivers are an important interface between the continents and oceans since they are involved in the delivery a key flux of organic compounds (autochthonous and allouchthonous) to the ocean, rapidly depositing them on shelves and margins (Saliot, Laureillard, Scribe, \& Sicre, 2001). Lipid classes have been used as molecular markers for understanding the origin and reactivity of organic matter (OM) and for tracing fluxes transferred between drainage basins, tributaries, rivers and their estuaries (Camacho-Ibar, Aveztau-Alczar, \& Carriquity, 2003; Oyo-Ita, Ekpo, Oros, \& Simoneit, 2010).

Several studies of the OM composition of tropical rivers have shown that much of the transported material is predominantly derived from highly degraded soil material (Ittekkot, 1988). Therefore, tracing OM sources in sediments has received considerable attention due to the importance of understanding OM cycling in the aquatic environment (Jaffe, Rushdi, Medeiros, \& Simoneit, 2006).

Besides being the primary membrane and energy storage in planktons, fatty acids (FAs) play important role in source characterization of OM in sediment (Aboul-Kassim \& Simoneit, 1996; Fahl \& Stein, 1999; Al-mutlaq, Standley, \& Simoneit, 2008), in hormone production (Irigoien, 2004), cell-cell signalling (Vardi et al., 2008), and chemical defence (Miralto et al., 1999). However, their utility as quantitative tracers of the different organic carbon sources is complicated by many factors: ambiguities in organic matter source are common due to the fact that individual FAs may differ in their diagenetic susceptibility during particle settlement through the water column (Wakeham, 1999; Mudge, 2005). Other factors that affect individual FAs include water temperature (Fileman, Pond, Barlow, \& Mantoura, 1998), dissolved oxygen concentration (Harvey \& Marko, 1997) and degree of sorption onto mineral matrices (Nissemann \& Schubert, 2006).

The role played by fatty alcohols (FALs) in evaluating aquatic sediments is sparse compared to FAs and sterols (Humrawali et al., 2009). Despite their usefulness, less attention has been paid to FALs as biomarkers on the basis of their source specificity. Also, detailed studies of their spatial distribution in tropical rivers are not numerous. Generally, application of lipid biomarkers in Sub-Saharan tropical coastal environments including 
Nigeria has not been thoroughly studied compared to other countries such as the USA, UK, Spain, Australia, China, where such studies have been applied since the 1970s.

Due to the lack of detail oceanographic and biogeochemical studies of the Niger Delta region, it is quite difficult to ascertain the important sources of terrigenous material in the region and to understand the effects and changes in the organic compositions of the recent sediments. A few organic geochemical studies of surface sediments from the Niger Delta coastal environments have focussed on the south-south geo-political area (Ekpo, Oyo-Ita, \& Wehner, 2005; Ekpo, Oyo-Ita, Oros, \& Simoneit, 2011; Oyo-Ita, Ekpo, Oros, \& Simoneit, 2010a, 2010b, 2010c); sediments from the south east geo-political area have not been previously described in terms of their lipid compositions and distribution. We report here the fatty acid (FA) and alcohol (FAL) compositions, sources and distributions of surface sediments from the Imo River, Southeast Niger Delta, Nigeria. The overall aims of the study were to characterise contemporary sources of the sedimentary OM and compare the results with those for other shallow and deep aquatic sedimentary environments.

\section{Materials and Methods}

\subsection{Study Area}

Imo River is one of the tributaries of the Nigerian SE rivers (Figure 1). It originates from the hill region of Imo State and flows through several towns, villages and farmland and empties directly into the Bight of Bonny which then flows into the Atlantic ocean. The river lies between $5^{\circ} 55^{\prime} \mathrm{N}$ and $7^{\circ} 1^{\prime} \mathrm{E}$. It is shallow, with the depth ranging from 1.0 to $18.0 \mathrm{~m}$ at flood tide and about $12.0 \mathrm{~m}$ maximum at ebb tide. The study area belongs to the low lying coastal deltaic plain of south eastern Nigeria; the terrain is virtually flat or gently undulating, sloping generally towards the Atlantic (Ezeayim \& Okereke, 1996). Because of this, part of the study area is generally flooded, particularly during the wet season, giving rise to greater in-wash of terrigenous materials to the river during this period. The entire river appears cloudy (except at congruence with other tributaries) as a result of the high suspended sediment load due to rapid weathering. These suspended particles may heat-raise the water temperature as well as increase sunlight absorption that is capable of causing reduced oxygen content in the river. These problems may limit growth of phytoplanktons as light penetration is also hindered.

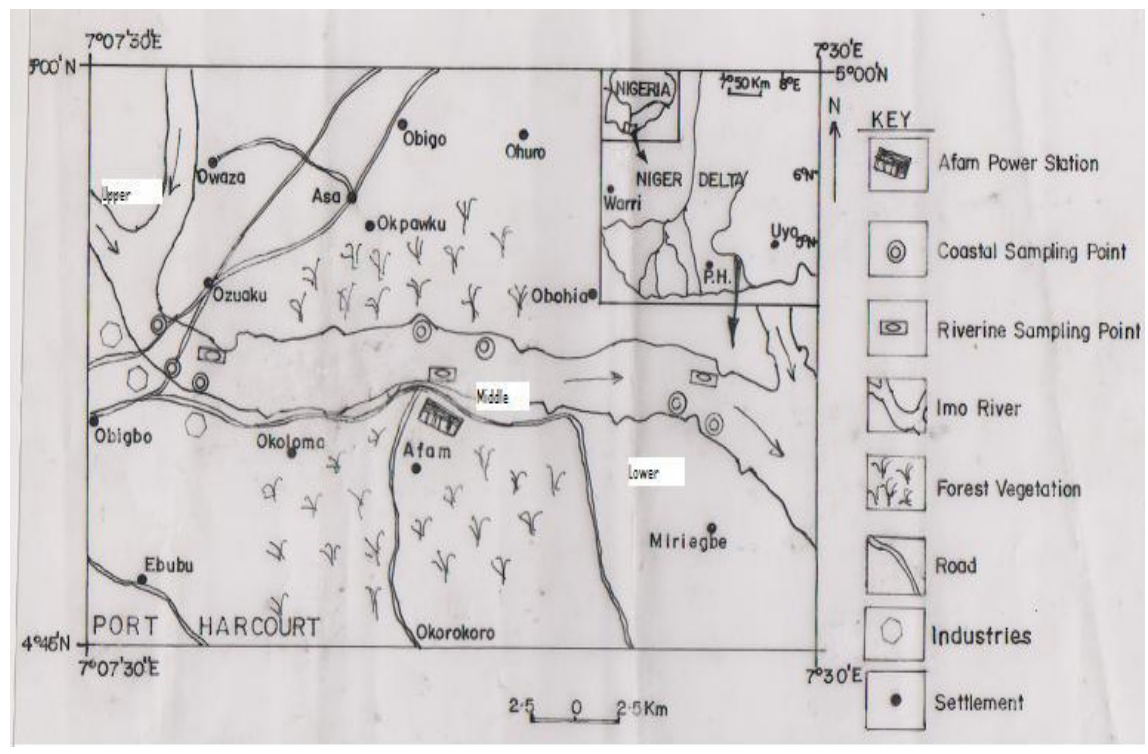

Figure 1. Sketch map of the study area showing sample locations

A combination of heavy rain and intense sunshine coupled with adequate soil nutrients generates a thick vegetation cover in the study area, the region supporting a dense angiosperm forest (Adefolalu, 1981). An important vegetation input to the river consists of floating grass on the shoreline which often forms large floating mats and mangrove. However, there are a few industries (e.g. Afam power staion) aligned near part of the riverbank and the prevalence of illegal oil refinery and bunkering activity resulting in spillage in the upper river. Geologically, the study area belongs to the southeast part of the Cretaceous and Tertiary sedimentary basin of the southern Niger Delta (Ezeayim \& Okereke, 1996). 


\subsection{Sample Collection}

A total of ten sediment samples covering ca. $90 \mathrm{~km}$ of the river were collected. These samples were selected to not only take advantage of a high biomass content such as from mangrove materials but also to minimise input from marine source as the sediments were not under direct tidal influence.

The river was divided into three zones (I, II and III) depending on the characteristic features of the environment (Table 1; Figure 1). Each zone afforded three samples. Samples collected from the lower river were not seriously affected by tide and salinity since they were obtained at about $15 \mathrm{~km}$ from the mouth of the river. Samples were collected using a van-Veen grab sampler, freeze-dried and sieved to obtain different particle size fractions. In order to ensure homogeneity in particle size, each sample was a composite of three from different assessment points. Samples from zone I (IS1, IS2, and IS3) were taken near a residential area (lower river); zone II samples (IS4, IS5, and IS6) were collected near a fish settlement (middle river) while zone III samples (IS7, IS8 and IS9) were taken near an industrial area (upper river). A distal sample was also collected upstream from a remote area (IS10; Table 1). All samples were stored in a freezer until analysis.

Table 1. Sample locations, geochemical parameters and characteristic features of the study area

\begin{tabular}{|c|c|c|c|c|c|c|c|c|c|c|}
\hline \multirow[t]{2}{*}{ Zone } & \multirow[t]{2}{*}{$\begin{array}{l}\text { Sample } \\
\text { Id }\end{array}$} & \multirow[t]{2}{*}{$\begin{array}{l}\text { Site } \\
\text { Feature }\end{array}$} & \multirow[t]{2}{*}{ Coordinate } & \multirow[t]{2}{*}{$\begin{array}{l}\text { TOC } \\
(\%)\end{array}$} & \multirow[t]{2}{*}{$\begin{array}{l}\text { EOM } \\
(\mathrm{mg} / \mathrm{kg})\end{array}$} & \multirow[t]{2}{*}{$\begin{array}{l}\text { Salinity } \\
(\mathrm{mg} / \mathrm{l})\end{array}$} & \multirow[t]{2}{*}{$\begin{array}{l}\text { Turbidity } \\
\text { (NTU) }\end{array}$} & \multicolumn{3}{|c|}{$\begin{array}{l}\text { Grain size } \\
\text { distribution (\%) }\end{array}$} \\
\hline & & & & & & & & Clay & Silt & Sand \\
\hline \multirow[t]{3}{*}{$\begin{array}{l}\text { Lower } \\
\text { (I) }\end{array}$} & IR1 & $\begin{array}{l}\text { Residential, } \\
\text { sparse } \\
\text { vegetation, }\end{array}$ & $\begin{array}{l}4^{0} 45^{\prime} 57 \mathrm{~N} \\
7^{0} 34^{\prime} 27 \mathrm{E}\end{array}$ & 2.4 & 2150 & 0.12 & 58 & 15.1 & 16.01 & 68.89 \\
\hline & IR2 & $\begin{array}{l}\text { sewage } \\
\text { discharge, } \\
\text { waste }\end{array}$ & $\begin{array}{l}4^{\prime \prime} 44^{\prime} 49 \mathrm{~N} \\
7^{0} 34^{\prime} 32 \mathrm{E}\end{array}$ & 2.72 & 1150 & 0.14 & 93 & 14.22 & 22.01 & 58.89 \\
\hline & IR3 & $\begin{array}{l}\text { water/street } \\
\text { dust runoff. }\end{array}$ & $\begin{array}{l}4^{\prime \prime} 44^{\prime} 47 \mathrm{~N} \\
7^{0} 35^{\prime} 29 \mathrm{E}\end{array}$ & 3.95 & 2850 & 0.11 & 47 & 20.2 & 20.1 & 51.7 \\
\hline \multirow[t]{3}{*}{$\begin{array}{l}\text { Middle } \\
\text { (II) }\end{array}$} & IR4 & $\begin{array}{l}\text { Fish } \\
\text { settlement, } \\
\text { thick }\end{array}$ & $\begin{array}{l}4^{0} 57^{\prime} 12 \mathrm{~N} \\
7^{0} 15^{\prime} 02 \mathrm{E}\end{array}$ & 3.5 & 3000 & $\mathrm{Nd}$ & 54 & 21.2 & 26.12 & 63.68 \\
\hline & IR5 & $\begin{array}{l}\text { vegetation, } \\
\text { agricultural } \\
\text { runoff, } \\
\text { engine }\end{array}$ & $\begin{array}{l}4^{\prime \prime} 58^{\prime} 01 \mathrm{~N} \\
7^{\circ} 14^{\prime} 00 \mathrm{E}\end{array}$ & 4.58 & 2950 & $\mathrm{Nd}$ & 62 & 25.2 & 20.75 & 47.05 \\
\hline & IR6 & $\begin{array}{l}\text { exhaust } \\
\text { emission, } \\
\text { wood/grass } \\
\text { burning. }\end{array}$ & $\begin{array}{l}4^{0} 57^{\prime} 59 \mathrm{~N} \\
7^{0} 15^{\prime} 00 \mathrm{E}\end{array}$ & 4.34 & 1700 & $\mathrm{Nd}$ & 75 & 26.5 & 24.4 & 47.1 \\
\hline \multirow[t]{4}{*}{$\begin{array}{l}\text { Upper } \\
\text { (III) }\end{array}$} & IR7 & $\begin{array}{l}\text { Industrial, } \\
\text { sparse } \\
\text { vegetation, }\end{array}$ & $4^{0} 57^{\prime} 59 \mathrm{~N}$ & 2.52 & 2250 & $\mathrm{Nd}$ & 116 & 4.1 & 6.8 & 89.1 \\
\hline & & $\begin{array}{l}\text { Oil spill, } \\
\text { engine } \\
\text { exhaust } \\
\text { emission. }\end{array}$ & $7^{0} 15^{\prime} 00 \mathrm{E}$ & & & & & & & \\
\hline & IR8 & & $\begin{array}{l}5^{0} 13^{\prime} 14 \mathrm{~N} \\
6^{0} 59^{\prime} 14 \mathrm{E}\end{array}$ & 2.42 & 406 & $\mathrm{Nd}$ & 122 & 10.1 & 15.4 & 84.5 \\
\hline & IR9 & & $\begin{array}{l}5^{0} 13^{\prime} 57 \mathrm{~N} \\
6^{0} 58^{\prime} 02 \mathrm{E}\end{array}$ & 3.21 & 550 & $\mathrm{Nd}$ & 103 & 4.1 & 4.8 & 91.1 \\
\hline $\begin{array}{l}\text { Distal } \\
\text { (upstream) }\end{array}$ & IR10 & Remote & $\begin{array}{l}5^{0} 16^{\prime} 19 \mathrm{~N} \\
6^{0} 58^{\prime} 49 \mathrm{E}\end{array}$ & 2.1 & 200 & $\mathrm{Nd}$ & 23 & 9.1 & 10.4 & 80.1 \\
\hline
\end{tabular}




\subsection{Analysis/Detection of FAs and FALs in Sediments}

Chromatographic grade $n$-hexane and iso-octane were used.

Bis (trimethylsilyl)trifluoroacetamide (BSTFA-Merck, Germany), neutral silica gel (70-230 mesh,Merck) and alumina (70-230 mesh-Merck) were extracted with $(2: 1, \mathrm{v} / \mathrm{v})$ dichloromethane (DCM)-MeOH in a soxhlet apparatus for $24 \mathrm{~h}$. After solvent evaporation, the silica and alumina were heated for $12 \mathrm{~h}$ at $120^{\circ} \mathrm{C}$ and $350^{\circ} \mathrm{C}$, respectively. 5\% Milli-Q-grade water was then added to the adsorbents to deactivate them.

Samples were homogenized with mortar and pestle and spiked with C13:1 FA and $5 \alpha-(\mathrm{H})$-cholestan-3- $\beta$-ol as surrogates prior to extraction (3x) with $\mathrm{MeOH}, \mathrm{DCM}$ and $n$-hexane using ultrasonic agitation. The extract was saponified with $30 \mathrm{ml} \mathrm{KOH} \mathrm{(6 \% )} \mathrm{in} \mathrm{MeOH}$ and the neutral components recovered by extraction with $3 \times 30 \mathrm{ml}$ $n$-hexane. The alkaline mixture was acidified to $\mathrm{pH} 2$ with $5 \mathrm{ml} \mathrm{HCl}$ and the acidic compounds recovered by extraction with $3 \times 30 \mathrm{ml} n$-hexane. The neutral compounds were fractionated on a column filled with silica ( $8 \mathrm{~g}$, bottom) and alumina ( $8 \mathrm{~g}$, top). Four fractions were obtained by successive elution with $40 \mathrm{ml} n$-hexane/DCM (8:2), $40 \mathrm{ml} n$-hexane/DCM (1:3), $20 \mathrm{ml} \mathrm{DCM} / \mathrm{MeOH}$ (95:5) and $40 \mathrm{ml} \mathrm{DCM} / \mathrm{MeOH}$ (9:1) (Garcia et al., 2004). The two most polar fractions were silylated $\left(1 \mathrm{~h}, 60^{\circ} \mathrm{C}\right)$ after dissolution in $100 \mu \mathrm{l} \mathrm{DCM}$ and addition of $100 \mu \mathrm{l}$ BSTFA. The FA fraction was methylated using $\mathrm{CH}_{2} \mathrm{~N}_{2}$ synthesized from Diazald (Aldrich,USA) as described elsewhere (Vogel, 1978).The fractions were dissolved in $100 \mu \mathrm{l} n$-hexane, cooled in ice and the distilled solution of $\mathrm{CH}_{2} \mathrm{~N}_{2}$ was added in small portions until gas evolution ceased and the yellowish colour remained.

Samples were analysed using gas chromatography (GC: Varian star 3400) with flame ionization detection (FID). A $30 \mathrm{~m}$ column $(0.25 \mathrm{~mm}$ id $)$ coated with DB-5 $(0.25 \mu \mathrm{m}$ film thickness; J \& W Scientific, USA) was used. Hydrogen was used as carrier gas. The oven temperature programme was $70^{\circ} \mathrm{C}(1 \mathrm{~min})$, to $140^{\circ} \mathrm{C}$ at $10^{\circ} \mathrm{C} / \mathrm{min}$, then to $310^{\circ} \mathrm{C}$ (held $30 \mathrm{~min}$ ). The detector temperature was $330{ }^{\circ} \mathrm{C}$. GC-mass spectrometry (GC-MS) were performed with a Fisons MD-800 quadrupole mass analyzer (THERMO Instruments, Manchester, UK.). Samples were injected in splitless mode at $300^{\circ} \mathrm{C}$ onto a $30 \mathrm{~m}$ column $(0.25 \mathrm{~mm}$ i.d.) coated with DB-5 $(0.25 \mu \mathrm{m}$ film thickness). Helium was the carrier gas. The temperature programme was as above. Mass spectra were recorded in the electron ionization mode at $70 \mathrm{eV}$ by scanning (1s) over between $\mathrm{m} / \mathrm{z} 50$ and 650. Ion source and transfer line were at $300{ }^{\circ} \mathrm{C}$. Data were acquired by means of a Perkin Elmer Nelson 900 interface connected to a PS-2 computer programme with the Nelson data treatment software. The software was used for quantification with reference to external standards of C-13:1 FA methyl ester (FAME) (for acids) and $5 \alpha-(\mathrm{H})$-cholestan-3- $\beta$-ol (for alcohols).

Samples and standards were repeatedly injected until less than 5\% depression was observed in the integrated area. FAs and FALs were identified by comparism of their retention times with those of the standards. The identity was confirmed by way of GC-MS.

\section{Results and Discussion}

\subsection{TOC Content of Sediments}

Sample locations, characteristic features of the environment and results of total organic carbon (TOC) content, extractable organic matter (EOM), salinity, turbidity and grain size distribution for the study area are presented in Table 1. EOM were in the range $200-3000 \mathrm{mg} / \mathrm{kg}$ dry weight (dw) minimising at station IR10 with a maximum value found at IR4. Salinity of the overlying water ranged from non-detection level in samples obtained from both the middle and upper portions of the river to 0.14 in lower river samples. The upper river (e.g. IR8) exhibited the highest turbidity value of $122 \mathrm{ntu}$ and a minimum value of $23 \mathrm{ntu}$ was found for the remote upstream station IR10.

TOC content for the sediments ranged from 2.10 to $4.58 \%$ with a mean value of 3.28 . The highest TOC content was measured at station IS5 followed by station IS6 (4.34\%) with the lowest value recorded at station IS10 located in a remote upstream area. Input of terrestrial OM to the aquatic environment is directly affected by the role of river current in the transport of compounds produced by terrestrial plants (Shi, Sun, Molina, Hodson, 2006). This phenomenon may explain the observed high TOC value measured at station IS6 (near shoreline) and most likely reflects a combination of transport of terrestrial OM by river current during flood episodes accompanying intense rainfall events and autochthonous production. Contribution of phytoplankton to TOC content in our samples is expected to be low due to the high suspended particulate matter in the river water which limits light penetration through the water column, thus reducing photosynthetic process with its accompanied drop in primary production.

Grain size distribution of the sediment also plays an important role in determining TOC. For instance, fine-grained sediments are reported to adsorb OM more than coarse sandy types with larger grain size (Hyun et 
al., 2002). The surface sediments covering the area under study are composed mainly of terrigeneous material consisting of predominantly sandy fraction (Table 1) probably because of the sheltered basin morphology and apparently high energy current conditions. The average proportion of sand was rather high at stations toward the upper portion of the river $(88.23 \%)$ and the remote upstream location $(80.10 \%)$. The lower and middle samples had a mean proportion of sand of $60 \%$ and $53 \%$, respectively. These coarse-grained samples correspond to the relief deposits formed under the more shallow high energy condition characteristics of the river, The TOC content of the sediments is typical of a coastal environment exhibiting high TOC contents for samples with high proportion of clay/silt fraction, whereas samples with high proportion of sandy fraction exhibited low TOC.

Comparing data with those for other aquatic sedimentary environments, the TOC values for the sediment are comparable to those for the Cross river system (ca.1.27-4.56\%) in the south-south geopolitical region of the Niger Delta (Oyo-ita et al., 2010a). This indicates that similar environmental and biogeochemical conditions are prevalent in the two river systems. Unlu and Alpar (2006) reported a lower TOC content (ca. 0.07-3.05\%) in surface sediments from Germlik Bay, Turkey where higher TOC values were observed in sediments from a deep trough area than those from shallow areas. Furthermore, much lower TOC content of range $0.32-0.95 \%$ was reported for Yangste River with comparable water depth to that of the study area, highlighting the importance of water depth as a factor that determines organic carbon accumulation in aquatic sediments. In addition, variation in the quality and quantity of OM input has been attributed to the varied TOC contents of coastal sediment from Egypt (ca. 1.0-9.1\%; Aboul- Kassim \& Simoneit, 1996) and surface sediments from Pulau, Tinggi, Malaysia (ca. 2-13\%; Humrawadi, 2009).

\subsection{Fatty Acid Distributions and Sources in Sediments}

The total FA (TFA) concentrations were in the range $1223-4460 \mathrm{ng} / \mathrm{g} \mathrm{dw}$ (Table 2) lower than the values for the top section of cores from the lake Kivu, East African rift valley (most likely due to the anoxic condition of the water column and greater primary productivity; Al-mutlaq et al., 2008), and are slightly higher than that found for sediment with shallow water depth of about $55 \mathrm{~m}$ (deeper than our case study) from the coastal zone of Ras Abu el-Darag, Gulf of Suez (probably a result of relatively reduced degradation efficiency in the Imo river water column). This later scenario is in agreement with numerous studies which provide evidence that shallow water depths $(<50 \mathrm{~m})$ favour high TFA concentrations in surface sediments (Nissemann \& Schubert, 2006; Rushdi et al., 2009). The TFA concentrations relative to EOM ranged between $1.3 \%$ and $16.2 \%$ with a mean value of $4.19 \%$ and maximizing in sample IS8 collected near an industrial/sparse vegetation area (zone III). This high relative TFA value at this station may reflect a relatively high bacterial input to the station. Generally, the abundances of the 26 FAs showing strong even/odd numbered predominance, and ranging from $\mathrm{C}_{14}$ to $\mathrm{C}_{39}$ were C19 (1.73-40.88\%), C16 (1.94-13.8\%), C24 (1.88-13.23\%) and C26 (1.88-15.42\%). The least abundant acid was i1 $8: 0(0.45-0.52 \%)$. These distributions are indicative of input of terrestrial, phytoplanktonic and bacterial lipid residues.

Many previous studies of aquatic surface sediments show that FAs are non-specific in terms of their source assignment (Camachor-Ibar et al., 2003; Al-Mitlaq et al., 2008). Despite this drawback some of the FAs could, however, still be assigned to dominant sources.

\subsubsection{Phytoplanktonic Origin of FAs}

Phytoplankton and zooplankton are in particular the most important sources of monounsaturated FAs, and polyunsaturated FAs (PUFAs) with 20 and 22 carbon atoms (Parrish, Abrajano, Budge, Helleur, \& Hudson, 2000; Zimmerman \& Canuel, 2001). In most phytoplanktons, the compositions of unsaturated FA are more abundant than their saturated counterparts except for the population of cyanophyceae (Lauther, Henri, Fibert, \& Jean, 1993). And in most cases the values of the total unsaturated FA to the total saturated FA (U/S) lies between 1.07 and 1.97 where the cyanophyceae are not the majority. Our results showed U/S values $<0.5$ for the entire samples, suggesting minor contribution of phytoplankton to the total fatty acid content (Table 2).

At the level of monounsaturated $\mathrm{FA}, \mathrm{C}_{16: 1}$ and $\mathrm{C}_{18: 1}$ clearly predominate the other monoenes in most phytoplankton, particularly where Bacillaryophyceae population is poorly represented (Lauther et al., 1993). Claustre, Marty, Cassiani, Dagaut, (1988) proposed that a diatom source in aquatic sediments may be determined by way of the 16:1/16:0 FA ratio and the sum of all FAs having 16 carbon atoms to the sum of all FAs having 18 carbon atoms $(\Sigma \mathrm{C} 16 / \Sigma \mathrm{C} 18)$. These authors postulated that increased values of these ratios represent increased proportions of diatoms. In our samples, detection of 16:107 in low levels and non-detection of C20 and C22 PUFAs reduce the likelihood of a major FA contribution from certain phytoplanktonic origin. This assertion is supported by the low values of $\Sigma \mathrm{C} 16 / \Sigma \mathrm{C} 18$ and 16:1/16:0 $(<1)$ ratios for most of the samples set (Table 2), highlighting relatively minor contribution of phytoplankton and diatoms to the OM flux in the river. However, 
the non-detection of PUFAs does not preclude the existence of certain population of phytoplankton in the river as the entire sediment is predominated by C16 FA (Figure 2a) usually assigned as having a phytoplanktonic origin in many aquatic environments. Lauther and his co-worker (1993) studied the variation in fatty acid composition of phytoplanktonic production in ponds and they found absence of 20 and 22 PUFAs in certain period of the year. This may likely explain the non-detection of these FAs in our samples at the time of sampling.

Table 2. Percentage compositions, concentrations (ng/g), geochemical ratios for fatty acids in extracts from surface sediments of the Imo River

\begin{tabular}{|c|c|c|c|c|c|c|c|c|c|c|}
\hline \multirow{2}{*}{ Parameter } & \multicolumn{3}{|c|}{ Zone I } & \multicolumn{3}{|c|}{ Zone II } & \multicolumn{3}{|c|}{ Zone III } & \multirow{2}{*}{$\begin{array}{c}\text { Distal (Upstream) } \\
\text { IS10 }\end{array}$} \\
\hline & IS1 & IS2 & IS3 & IS4 & IS5 & IS6 & IS7 & IS8 & IS9 & \\
\hline TFA & 3900 & 2374 & 3838 & 4242 & 4248 & 3243 & 4460 & 3253 & 4266 & 1223 \\
\hline$\sum \mathrm{C}-16^{\mathrm{a}}$ & 530 & 220 & 925 & 865 & 870 & 151 & 964 & 283 & 610 & 151 \\
\hline$\sum \mathrm{C}-18^{\mathrm{a}}$ & 595 & 405 & 1035 & 1080 & 910 & 140 & 1190 & 500 & 653 & 175 \\
\hline$\sum \mathrm{LCFA}^{\mathrm{a}}$ & 1960 & 1122 & 1125 & 1481 & 1634 & 2437 & 1387 & 1590 & 2019 & $259(64.36)^{\mathrm{c}}$ \\
\hline$\sum \mathrm{SCFA}^{\mathrm{a}}$ & 1282 & 981 & 1477 & 1535 & 1601 & 622 & 1712 & 1105 & 1798 & $785(38.42)^{\mathrm{c}}$ \\
\hline $18: 2 \omega 6^{\mathrm{b}}$ & 2.95 & 2.74 & 4.55 & 4.95 & 4.98 & 5.02 & 3.92 & 1.54 & 0.70 & $10.06(\quad)$ \\
\hline $18: 3 \omega 3^{\mathrm{b}}$ & 4.87 & 3.21 & 8.54 & 7.30 & 6.59 & 8.96 & 7.84 & 2.30 & 1.28 & $16.76(6.95)^{\mathrm{c}}$ \\
\hline$\sum \mathrm{C}-16 / \sum \mathrm{C}-18$ & 0.92 & 0.54 & 0.89 & 0.67 & 0.95 & 1.07 & 0.78 & 0.57 & 0.93 & $0.86(4.44)^{\mathrm{c}}$ \\
\hline 18:1/18:0 & 0.89 & 1.40 & 0.90 & 0.76 & 0.67 & - & 0.68 & 0.77 & 0.58 & - \\
\hline $\mathrm{TFA}^{\mathrm{d}}$ & 1.80 & 2.01 & 1.30 & 1.40 & 1.50 & 0 & 2.01 & 16.20 & 7.70 & $6.10(4.19)^{\mathrm{c}}$ \\
\hline $\mathrm{U} / \mathrm{S}$ & 0.20 & 0.12 & 0.49 & 0.41 & 0.31 & 0.06 & 0.34 & 0.21 & 0.12 & 0.17 \\
\hline $16: 1 / 16: 0$ & 0.21 & 0.16 & 0.09 & 0.05 & 0.03 & 0.14 & 0.78 & 0.43 & 0.56 & 0.66 \\
\hline i15:0 & & 1.49 & 0.56 & 0.59 & 0.47 & 0.16 & 0.85 & 0.74 & 3.11 & 0.84 \\
\hline i17:0 & 0.08 & 0.98 & 0.37 & 0.46 & 0.21 & $\mathrm{Nd}$ & 0.63 & 0.87 & 2.82 & 0.72 \\
\hline a17:0 & $\mathrm{Nd}$ & 0.07 & $\mathrm{Nd}$ & $\mathrm{Nd}$ & $\mathrm{Nd}$ & $\mathrm{Nd}$ & 0.01 & 0.03 & 0.08 & $\mathrm{Nd}$ \\
\hline $19: 0$ & 11.42 & 20.30 & 8.25 & 7.76 & 8.31 & 1.62 & 8.67 & 12.64 & 43.24 & 1018 \\
\hline
\end{tabular}

N/B: Concentration expressed in ng/g dry weight; $\mathrm{nd}$ =not detected; (a) Composition relative to TFA., (b) Mean composition (\%), (c) Mean relative concerntration (\%) with respect to total extracts.

Ratio values of unsaturated and saturated FAs of various carbon numbers (e.g. 18:1/18:0) have also been used to indicate an input from fresh OM. In our samples, low values of this ratio were found (Table 2), suggesting that most of the OM flux to the sediment at the time of sampling were aged (not fresh). Quantitative comparison of the FAs of phytoplanktonic origin in our study with those for other aquatic sediments is difficult due to the possibility of contribution of FAs with $\mathrm{C} 20: 0$ and $\mathrm{C} 22: 0$ from unspecified terrestrial OM.

\subsubsection{Bacteial Origin of FAs}

Bacteria are typical sources of odd and branched chain FAs especially the iso- and anteiso-acids, i15:0, i17:0 and a17:0 have been reported by several researchers (Harvey \& Marko, 1997). Other FAs reported to be produced by both aerobic and anaerobic bacteria are 15:0 and 17:0 (Parish et al., 2000). The sum of these FAs has been used to estimate the bacterial contribution to riverine and estuarine systems (Harvey \& Marko, 1997; Parish et al., 2000). However, according to these authors, this bacterial marker should be used with caution because of conflicting theories concerning their usefulness. In the light of these controversies, comparison of the levels of bacterial contribution between our samples and other aquatic sediments would be difficult. Therefore, the relative levels of bacterial contribution $\left(\Sigma_{\text {bact. }}\right.$ ) were determined among sampling stations in our study (Figure 3a).

Gong and Hollander (1997) were able to trace higher contribution of bacterial FAs in sediments from anoxic depocenter than in oxic sediments from the periphery of the Santa Monica Basin. The detection in relatively low levels of iso- and anteiso- i15:0 and i17:0 types as well as the absence of $\beta$-hydroxy FA (which indicates absence 
of gram negative bacteria) most likely is a reflection of the oxic nature of the sediment and sensitivity of gram negative bacteria to photo-degradation (a consequence of increased light penetration through the shallow water column) (Michele et al., 1996).

Our calculation of the levels of bacterial contribution was based on sum of i18:0, 15:0 i15:0 17:0, i17:0, a1 7:0 as well as 19:0 FAs and dicarboxylic acid (an indicator of microbial activity; Nierop, Naafs, Eglinton, 2003). The detection of high levels 19:0 acid in some of the samples (Figure $2 b$ ) may be a result of input from a different consortium of bacteria with different physiological structure inhabiting petroleum infested environment. This suggestion is borne out of the observation that the levels of 19:0 acids were high in samples collected near oil spills (e.g. IS8 and IS9; industrial site) where relatively high concentrations of i15:0, i17:0 and a17:0 were found. Analysis of soil OM (SOM) by Nierop et al. (2003) showed the presence of 19:0 acid reported to be derived from bacteria rather than terrestrial sources. Therefore, for this reason, stations IS8 and IS9 were found to have relatively high proportions of bacterial contribution to the river (Figure3a, b). Our results show that ca. 14.36\% of the TFAs represents a contribution from bacteria.

\subsubsection{Terrestrial Origin of FAs}

In many aquatic environments, there is interest in determining the extent of contribution from terrestrial plants. Even numbered, saturated long-chain FAs $>\mathrm{C} 24$ in aquatic sediments are typically associated with an input of OM from terrestrial higher plants (Parish et al., 2001; Camacho-Ibar et al., 2003; Al-mutlaq et al., 2008). For comparison with other aquatic sediments, the sum of C24-C39 (इC24-C39) concentrations of long chain FAs (LCFAs) were calculated. The values were in the range $259-2437 \mathrm{ng} / \mathrm{g} \mathrm{dw}$, with contribution relative to the TFAs ranging from $21.18-75.16 \%$ (mean $64.36 \%$; Table 2 ). The highest value of terrestrial OM $\left(\Sigma_{\text {Terri }}\right)$ was found in sample IS6, obtained near the shoreline (fish settlement/thick mangrove vegetation stands).
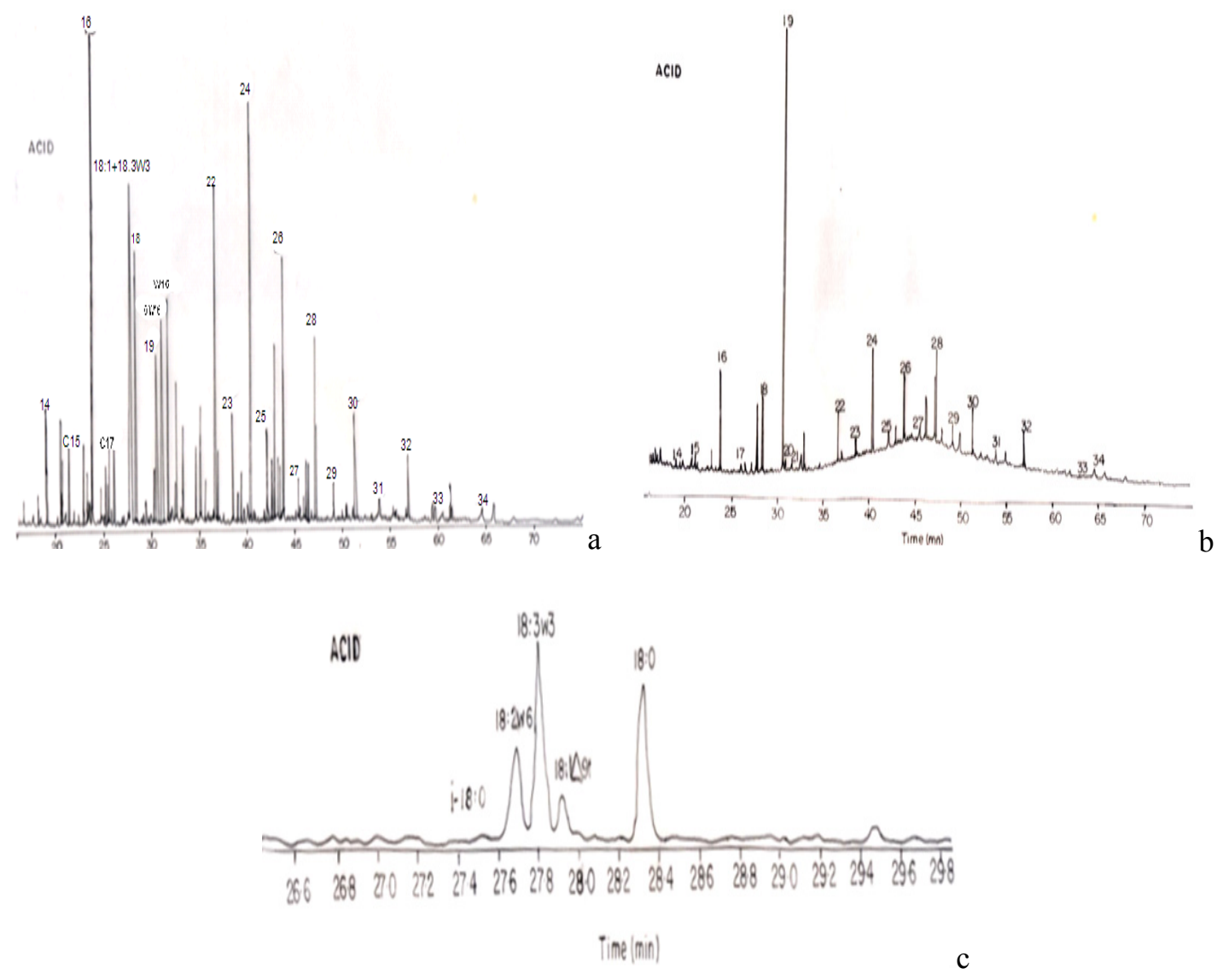

Figure 2a,b and c. GC-MS trace (total ion current) for fatty acids indicating dominance of (a) b and c: GC-MS trace (total ion current) for fatty acids indicating dominance of (a) hexadecanoic acid (C16), (b) nonadecanoic acid (C19) and (c) saturated, unsaturated and branched octadecanoic acid (iC18) in extracts from sediment of the Imo river 


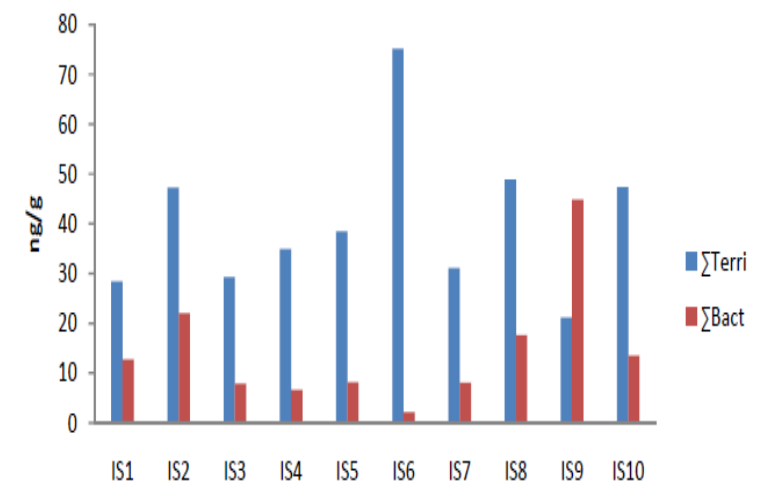

Station

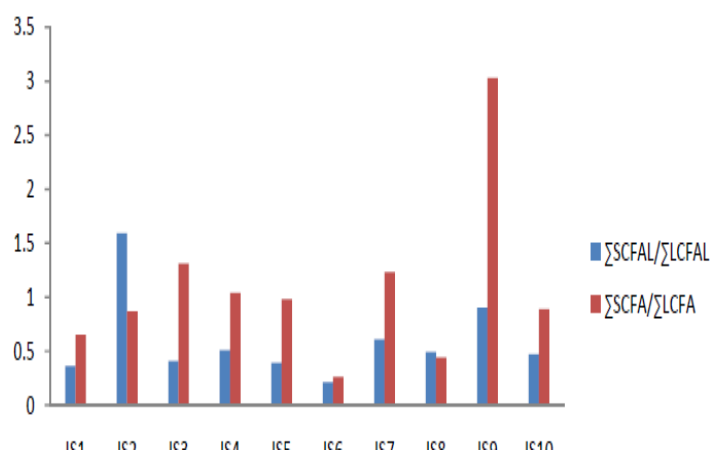

$\begin{array}{llllllllll}151 & 152 & 153 & 154 & 155 & 156 & 157 & 158 & 159 & 1510\end{array}$

Station

a

b

Figure 3a and b. Distribution of (a): Fatty acids of terrestrial and bacterial origins and (b): Ratio of sum of short chain and long chain compounds among sampling stations of the Imo river

Table 3. Percentage compositions, concentrations and geochemical ratios for acyclic alcohols in extracts from surface sediments of the Imo River

\begin{tabular}{lllllllllll}
\hline Parameter & \multicolumn{3}{l}{ Zone I } & \multicolumn{3}{c}{ Zone II } & \multicolumn{3}{l}{ Zone III } & Distal \\
\cline { 2 - 11 } & IS1 & IS2 & IS3 & IS4 & IS5 & IS6 & IS7 & IS8 & IS9 & IS10 \\
TFAL & 1682 & 1270 & 286 & 292 & 391 & 557 & 497 & 2229 & 1530 & 333 \\
$\sum$ SCFAL $^{\mathrm{a}}$ & 425 & 779 & 83 & 99 & 110 & 128 & 204 & 900 & 488 & 158 \\
$\sum_{\text {LCFAL }^{\mathrm{a}}}$ & 1174 & 491 & 203 & 193 & 280 & 423 & 292 & 1820 & 1042 & 175 \\
Phytol $^{\mathrm{a}}$ & 180 & 120 & 195 & 500 & 453 & 475 & 321 & 296 & 75 & 345 \\
${\mathrm{C}-22^{\mathrm{b}}}^{29.73}$ & 9.45 & 39.51 & 39.38 & 42.25 & 37.74 & 31.22 & 18.32 & 26.47 & 7.51 \\
& & & & & & & & & & $(28.16)^{\mathrm{c}}$ \\
C-24 $^{\mathrm{b}}$ & 22.29 & 8.24 & 13.29 & 13.01 & 14.08 & 16.17 & 11.08 & 15.21 & 18.95 & 10.51 \\
& & & & & & & & & & $(14.29)^{\mathrm{c}}$ \\
LCFAL $^{\mathrm{b}}$ & 74.73 & 38.65 & 70.98 & 66.1 & 71.83 & 77.01 & 58.91 & 67.02 & 68.19 & 52.55 \\
& & & & & & & & & & $(64.60)^{\mathrm{c}}$ \\
SCFAL $^{\mathrm{b}}$ & 25.27 & 61.34 & 29.02 & 33.9 & 28.17 & 23.01 & 41.09 & 32.98 & 31.81 & 47.45 \\
& & & & & & & & & & $(35.49)^{\mathrm{c}}$ \\
TFAL $^{\mathrm{d}}$ & 0.7 & 1.1 & 1.01 & 0.1 & 0.1 & 0.3 & 2.2 & 5.5 & 2.7 & 1.70 \\
& & & & & & & & & & $(1.54)^{\mathrm{c}}$ \\
\hline
\end{tabular}

N/B:

(a) Concerntrations expressed in $\mathrm{ng} / \mathrm{g}$ dry weight

(b) Percentage composition relative to TFAL

(c) Mean relative concerntration (\%) with respect to total extracts

(d) Mean composition (\%) 


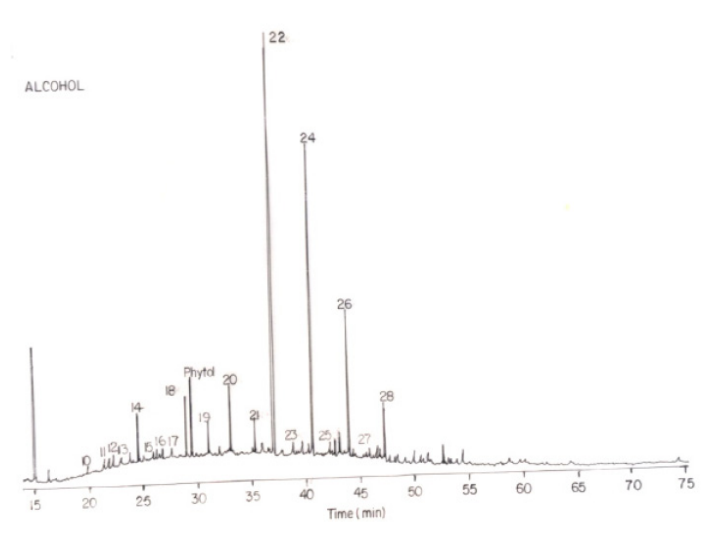

Figure 4. GC-MS trace (total ion current) for acyclic alcohols, indicating variation in phytol contribution to study area

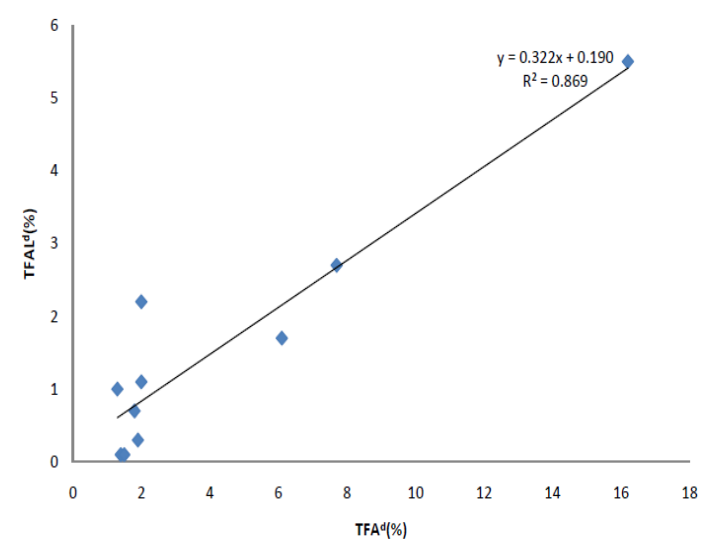

Figure 5. Relationship between relative concentrations of TFA ${ }^{\mathrm{d}}$ versus TFAL $^{\mathrm{d}}$

These values were more than three orders of magnitude higher than those reported for the top sections of sediment cores from the Northern Gulf of Califonia. The relatively high terrestrial contribution to the river in the present study may be due to the greater in-wash of SOM occasioned by flood episodes accompanying intense rainfall events.

Alternatively, the 18:2 $\omega 6$ and 18:3 $\omega 3$ FAs found to be elevated in most terrestrial plants may be used as terrestrial markers from an examination of terrestrial plant samples (Al-mutlaq et al., 2008). According to these authors, an arbitrary threshold of $2.5 \%$ relative to TFAs has been assigned to these indicators. On this basis, samples with values above this may be considered to have a significant terrestrial OM contribution. Our results for these markers are in agreement, showing values $>2.50 \%$ at most stations except those stations with a greater influence of petroleum residues (Table 2), supporting a dominant terrestrial contribution to OM flux in the river. Other FAs described by Nierop et al. (2003) as being derived from suberized tissue of roots such as $\alpha, \omega$ alkanedioic acid ( $\alpha \omega 16), 18: 1 \Delta 9$ and $\omega$-hydroxy-alkanoic acids $[\omega(\mathrm{OH}) 16]$, were also detected in appreciable levels in our samples (Figure 2a, c). Furthermore, in support of this terrestrial source for $\omega(\mathrm{OH}) 16$, Goni \& Hedges (1990) in their experiment on $\mathrm{CuO}$ oxidation of sedimentary materials from different aquatic environments (lacustrine, riverine and marine) yielded an assortment of non-lignin reaction products, among which long chain $\mathrm{C}_{1}-\mathrm{C}_{18}$ hydroxy FA have been identified with unique structural characteristics, suggesting their origin from cutin which is present in soft tissues of vascular plants. However, the low contribution of $\alpha, \omega 16$ compared to other terrestrial unsaturated (e.g. 18:1 $\Delta 9$ ) and hydroxyalkanoic acids is in line with reported data for cork. In addition, the presence of this dicarboxylic acid $(\alpha \omega 16)$ in our samples is somewhat remarkable as it is supposed to be a marker for oxidative degradation of unsaturated compounds (Grasset \& Ambles, 1998) and thus not likely to occur in fresh roots. Although, some studies have revealed the presence of $\alpha, \omega-16$ in SOM, it is not always found in aquatic sediments. Due to the oxic nature of the sediments under study and the proximity of some sampling points to the shoreline, it is most likely that the compound was diagenetically formed via oxidation of the terminal $\omega$-hydroxyalkanoic acid (a major component of the suberized tissue of root and/or non-lignin cutin derived) or the microbial metabolism of terrestrial plant detritus.

\subsection{Acyclic Alcohol Distributions and Sources in Sediments}

Total fatty alchol (TFAL) concentrations ranged from $286-2229 \mathrm{ng} / \mathrm{g} \mathrm{dw}$ (Table 3) about 1.5 order of magnitude higher than those recorded for surface sediment from Pulau, Tinggi, Malaysia. The FAL abundances relative to total extracts ranged between $0.1 \%$ and 5.5 (mean 1.54\%) and maximized in sample IS8 obtained near an industrial/sparse vegetation cover area (zone iii). The seventeen FALs had a strong even predominance and ranged from $\mathrm{C} 10-\mathrm{C} 28$, maximizing at $\mathrm{C} 22$ and $\mathrm{C} 24$ (Figure 4a, b). The data reflect a mixture of compounds derived from aquatic and terrestrial OM. The most abundant n-FALs are long chain (LCFALs: C20-C28) accounting for $64.60 \%$ of the TFALs while the short-chain group (SCFALs: C10-C20) accounted for $35.40 \%$ (Table 3). Individually, the two major compounds quantified are C22 and C24. C22 the former comprising $28.16 \%$ of the TFALs with a concentration ranging from $25-500 \mathrm{ng} / \mathrm{g}$ dry wt. (mean $230 \mathrm{ng} / \mathrm{g}$ ) minimising at station IS10 and maximizing at station IS5 near fish settlement/thick mangrove vegetation cover. The next most abundant compound is $\mathrm{C} 24$, which constitutes $14.29 \%$ of the TFALs with concentrations ranging from 35-415 
ng/g dry wt. (mean $141 \mathrm{ng} / \mathrm{g}$ ) minimising at station IS2 and maximizing at station IS1 near residential area.

Terrestrial plants utilise FALs as waxes coating for prevention of desiccation and these compounds are dominated with long chain length $\left(\mathrm{C}_{22}-\mathrm{C}_{32}\right)$. In contrast, aquatic organisms synthesize short chain compounds with peak chain of $\mathrm{C}_{14}$ and $\mathrm{C}_{16}$. Bacteria also produce FALs but these can be odd chain length and contain branches (Mudge, 2005). Although few data are available directly on FALs in bacteria, Parkes and Taylor, (1983) suggest that the detection of anteiso $\mathrm{C}_{15}$ compounds may be indicative of sulphate reducing bacteria. 18:1 FALs has been found in diatoms and green algae (Berge, Grougou, Dubacq, \& Durand, 1995). No iso and anteiso as well as very low levels of mono-unsaturated FALs were detected in our samples, thus reducing the likelihood of major autouchthonous OM contribution to the river.

The role of FALs as biomarkers is limited because of a lack of specificity (e.g. difficulty in discriminatimg between artificially and naturally produced FALs), making it almost impossible to identify a single natural source for each compound (Midge, 2005). However, many studies have established that the major input of OM to the aquatic environment can still be assessed on the basis of the carbon number range. The ratio of short chain (SCFAL) to long chain (LCFAL) compounds has been used to assess the predominance of an aquatic or terrestrial contribution (Humrawali, 2009). A value of 1 indicates an equal contribution from both aquatic and terrestrial sources. Values $>1$ indicate a greater contribution from aquatic source while a value of $<1$ implies a greater input of terrestrial OM. In our case, the calculated values of $\Sigma(\mathrm{C} 10-\mathrm{C} 20) / \Sigma(\mathrm{C} 21-\mathrm{C} 28)$ were plotted for both alcohols and acids in Figure $3 \mathrm{~b}$ and confirm the dominance of terrigenous OM input at most stations except stations IS2, IS8 and IS9 where petroleum infestation was high. The relatively high microbial input at these stations may be a result of high bacterial activity associated with petroleum pollution. Therefore, both the distribution pattern and the ratio support the high proportion of terrestrial OM input to the river.

Although SCFALs are reported to be derived predominantly from phytoplankton and zooplankton, Seguel, Mudge, (2005) assigned an unspecified terrigenous source for these compounds. In the present study, we suggest that planktons might not have been the exclusive sources of SCFALs in the river and that unspecified terrestrial material may be involved, particularly due to the proximity between some of the sampling stations and terrigenous sources. In support of this deduction, Nierop et al. (2003) reported the presence of SCFALs in Dutch coastal dune soil, derived from suberized tissue of oak root. Thus, in-wash of SOM via river currents following intense rain fall events could contribute SCFALs to the river.

It appears that detection of appreciable amounts of iso and anteiso FALs and FAs in aquatic systems requires: (i) the presence of a high abundance of $\mathrm{C}_{14}-\mathrm{C}_{18}$ straight chain fatty compounds produced by planktons, (ii) a deeper water column that allows sufficient time for in situ bacterial metabolic synthesis of iso and anteiso compounds from these short chain (straight) compounds before particle settlement on the bottom sediment and (iii) reducing or sub-oxic condition for the sedimentary environment. Hence, the detection in relatively low levels of anteiso or iso compounds in our study area may be due to low primary productivity, oxic as well as the shallow water column. This scenario is quite different from that in other deeper and anoxic aquatic sediments such as in the Pulau Sea in Malaysia where much higher abundances of iso and anteiso FALs ( $>70 \%$ of the TFAL) were reported (Humrawali, 2009). A plot of the relative concentrations of TFAs and TFALs (Figure 5) shows a strong correlation coefficient $\left(\mathrm{r}^{2}-0.869, \mathrm{p} \geq 0.01\right)$. This implies that the paired variables are dominantly derived from a common source and highlights the usefulness of FALs as source indicators in addition to commonly used biomarkers such as FAs and sterols.

One of the most abundant acyclic alcohols in the environment is phytol (Jeng \& Huh, 2004), an isoprenoid alcohol derived from diagenesis of chlorophyll. Similar trend was observed in our case study (Table 3; Figure 4a, b). The variation in phytol levels reflects differences in primary productivity and algal growth among sampling stations (Brettum, 1994), a consequence of the variation in nutrients influx from nearby agricultural activity. This deduction is based on the observation that among the sampling stations, stations near fish settlement where the inhabitants engage in active fishing and farming activity were found to have high abundances of phytol. However, it may also reflect the occurrence of varied input from the surrounding vegetation, as observed for the n-C20 - C28 FALs. Differentiation or dominant input between these two major sources could not be established in our samples on the basis of molecular signature only. However, a correlation between long chain fatty alcohol and phytol concentrations indicates poor relationship between these variables $\left(r^{2}=0.02 ; p>0.01\right)$, suggesting a minor contribution of phytol from the surrounding vegetation. Stable carbon isotope analysis could be useful in this regard. In our case study, levels of phytol could not be used to assess primary productivity due to possible input from terrestrial plants. 


\section{Conclusions}

The relatively low TOC content determined for the Imo River sediments may be due to its characteristic sheltered basin morphology dominated by an overwhelmingly high proportion of sand, apparent high energy current conditions and probable low primary productivity. Contribution from surrounding vegetation appears to dominate the distribution of FAs and FALs in the study area with the proportion of TFALs ca. 6 times higher than that for surface sediments from Pulau, Tinggi, Malaysia and the total mean FA concentration ca. 9 times lower than that reported for surface sediment from Kivu lake, East Africa rift valley. The contribution of planktons to the river, though minor, could not be estimated because of the possible influx of short chain compounds derived from an unspecified terrestrial source.

The detection in relatively low amounts of i15:0 and i17:0 as well as of a17:0 compounds may be a reflection of the oxic and shallow water column conditions as well as the low phytoplanktonic contribution that preclude metabolic conversion of $\mathrm{C}_{14}-\mathrm{C}_{18}$ by in situ bacteria to iso and anteiso compounds. The dominance of 19:0 acid in some of the samples is associated with an input of certain population of bacteria with different physiological structure that inhabit petroleum contaminated environment. The present investigation represents the first detailed study of FA and FAL distributions, fate and their relative source implications in sediments from the Imo River.

\section{Acknowledgements}

We thank the management and laboratory staff of Fugro Nig. Ltd. Port Harcourt, Nigeria for their assistance in the comprehensive analysis of our fractions by GC-MS at relatively low cost and our postgraduate students who assisted in field work. We are also grateful to the laboratory staff of the Pure and Applied Chemistry Department for assistance with the preliminary investigation of our samples.

\section{References}

Aboul-Kassim, T. A. T., \& Simoneit, B. R. T, (1996). Lipid geochemistry of surficial sediments from the coastal environment of Egypt: I-Aliphatic hydrocarbon characterization and sources. Marine Chemistry, 54, 135-158. http://dx.doi.org/10.1016/0304-4203(95)00098-4

Adefolalu, D. O. (1981). The weather and climate of Calabar, development of geography and regional planning. University of Calabar, Nigeria: In Lowenberg and Kenzel.

Al-mutlaq, K. F., Standley, L. J., \& Simoneit, B. R. T. (2008). Composition and sources of extractable organic matter from a sediment corer in Lake Kivu, East African rift valley. Applied Geochemistry, 23, 1023-1040. http://dx.doi.org/10.1016/j.apgeochem.2007.07.013

Berge, J. P., Grougou, J. P., Dubacq, J. P., \& Durand, P. (1995). Reassessment of lipid composition of the diatom, Skeletonema costatum. Phytochemistry, 39, 1017-1021. http://dx.doi.org/10.1016/0031-9422(94)00156-N

Brettum, P. (1994). Acidification of the humic lake Skjervatjern; effects on the volume and species composition $\begin{array}{llll}\text { of } & \text { Ehytoplankton. } & \text { Environment } & \text { International, }\end{array}$ http://dx.doi.org/10.1016/0160-4120(94)90115-5

Camachor-Ibar, V. F., Aveytua-Alczar, L., \& Carriquiry, J. D. (2003). Fatty acid reactivities in sediment cores from the Northern Gulf of California. Organic Geochemistry, 34, 425-439. http://dx.doi.org/10.1016/S0146-6380(02)00211-5

Canuel, E. A., \& Martens, C. S. (1996). Reactivity of recently deposited organic matter: degradation of lipid compounds near the sediment-water interface. Geochimica et Cosmochimica Acta, 60, 1793-1806. http://dx.doi.org/10.1016/0016-7037(96)00045-2

Claustre, H., Marty, J., Cassiani, L., \& Dagaut, J. (1989). Marine Microbial Food Webs, 3, 51-53.

Ekpo, B. O., Oyo-ita, O. E., Wehner, H. (2005). Even $n$-alkane/alkene predominances in surface sediments from the Calabar River, SE Niger Delta, Nigeria. Naturwissenschaften, 92, 341-346. http://dx.doi.org/10.1007/s00114-005-0639-8

Ekpo., B. O., Oyo-Ita., O. E., Oros, D. H., \& Simoneit, B. R. T. (2012). Distribution and sources of polycyclic aromatic hydrocarbons in surface sedimentsfrom Cross River estuary, SE Niger Delta, Nigeria. $\begin{array}{lllll}\text { Environmental Monitoring and } & \text { Assessment, }\end{array}$ http://dx.doi.org/10.1007/s10661-011-2019-5

Ezeayim, V., \& Okereke, C. A. (1996). The effect of petroleum activities in Nigerian soil environment. Global Journal of Pure and Applied Sciences, 11, 285-297.

Fahl, K. \& Stein, R. (1999). Biomarkers as organic-carbon-source andenvironmental indicatots in the Late 
Quarternary Arctic Ocean: problems and perspectives. Marine Chemistry, 63, 293-209. http://dx.doi.org/10.1016/S0304-4203(98)00068-1

Fileman, T. W., Pond, D. W., Barlow, R. G., \& Mantoura, R. F. C. (1996). Vertical profiles of pigments, fatty acids and amino acids: evidence for undegraded diatomaceous materials sedimenting to the deep ocean in the Bellingshausen Sea, Antarctica. Deep Sea Research, 45, 333-346.

Garcia, T., Lopez, J. F., \& Grimalt, J. O. (2004). Fatty acids, hydrocarbons, sterols and alkenones of microbial mats from coastal ecosystems of the Ebro Delta. ORPHELIA, 58, 189-194.

Goni, M. A., \& Gedges, J. I. (1990). Cutin-derived CuO reaction products from purified cuticles and tree leaves. Geochimica et Cosmochimica Acta, 54, 3065-3072. http://dx.doi.org/10.1016/0016-7037(90)90122-2

Gong, C., \& Hollander, D. J. (1997). Differential contribution of bacteria to sedimentary organic matter in oxic and anoxic environments, Santa Monica Basin, California. Organic Geochemistry, 26, 545-563. http://dx.doi.org/10.1016/S0146-6380(97)00018-1

Grasset, L., \& Ambles, A. (1993). Structure of humin and humic acid from acid soil as revealed by phase transfer $\begin{array}{lllll}\text { catalysed } & \text { hydrolysis. } & \text { Organic } & \text { Geochemistry, } & 29,\end{array}$ http://dx.doi.org/10.1016/S0146-6380(98)00193-4

Harvey, R. H., \& Marko, S. A. (1997b). Kinetics of phytoplankton decay during simulated sedimentation: changes in lipids under oxic and anoxic conditions. Organic Geochemistry, 27, 129-140. http://dx.doi.org/10.1016/S0146-6380(97)00077-6

Humrawali, N. (2009). Fatty alcohols in surface sediments from Pulau Tinggi, Johor, Malaysia. European Journal of Scientific Research, 32, 419-429.

Hyun, J. H., Ju, S. j., \& Harvey, H. R. (2002). Faecal contamination associated with local reclamation activity in the Han River Estuary. Journal of the Korean Society of Oceanography, 37, 1-8.

Ittekkot, V. (1988). Global trends in the nature of organic matter in river suspensions. Nature, 332, 436-438. http://dx.doi.org/10.1038/332436a0

Jaffe, R., Rushidi, A. I., Medeiros, P. M., \& Simoneit, B. R. T. (2006). Natural Product biomarkers as indicators of sources and transport sedimentary organic matter in a sub tropical river. Chemosphere, 64, 1870-1884. http://dx.doi.org/10.1016/j.chemosphere.2006.01.048

Jeng, W. H., \& Huh, C. A. (2004). Lipids in suspended matter and sediments from East China Sea Shelf. Organic Geochemistry, 35, 647-660. http://dx.doi.org/10.1016/j.orggeochem.2003.12.002

Lauther, A. M., Henri, C., Filbert, M., \& Jean, L. (1993). Variations in fatty acid composition of phytoplanktonic production in sewage treatment ponds at Meze. Effect on the valorization of microalgal biomass. Biochemistry \& Physiology, 104, 769-773.

Michele, M., Giulio, B., Poulo, G., Angelis, V., \& Giulio, J. (1996). Meso-substituted cationic purphyrins as efficient photosensitizers of gram negative and gram positive bacteria. Journal of Photochemistry and Photobiology, 3, 153-157.

Mudge, S. M. (2005). Fatty alcohols- a review of their natural synthesis and environmental distribution. The Soap and Detergent Association, 132, 1-141.

Nierop, K. G. J., Naafs, D. F. W., \& Eglinton, T. I. (2003). Occurrence and distribution of ester-bound lipids in Dutch costal dune soils along a $\mathrm{pH}$ gradient. Organic Geochemistry, 34, 719-731. http://dx.doi.org/10.1016/S0146-6380(03)00042-1

Nissemann, J., \& Schubert, C. J. (2006). Fatty acid biogeochemistry of sediment from the Chilean coastal upwelling region : sources and diagenetic changes. Organic Geochemistry, 37, 626-647. http://dx.doi.org/10.1016/j.orggeochem.2005.11.004

Oyo-ita, O. E., Ekpo, B. O., Oros, D. R., \& Simoneit, B. R. T. (2010a). Distributions and sources of aliphatic hydrocarbons and ketones in surface sediments from the Cross river estuary, S.E. Niger Delta, Nigeria. Journal of Applied Sciences in Environmental Sanitation, 5, 1-11.

Oyo-ita, O. E., Ekpo, B. O., Oros, D. R., \& Simoneit, B. R. T. (2010b). Identification of $5 \beta$-stanones as tracers for input from sewage and animal husbandry in surface sediments from the Cross river estuary, S. E. Niger Delta, Nigeria. Journal of Applied Sciences in Environmental Sanitation, 5, 13-22.

Oyo-Ita, O. E., Ekpo, B. O., Oros, D. R., \& Simoneit, B. R. T. (2010c). Occurrence and sources of triterpenoids 
methyl ethers and acetates in sediments of the Cross River System of Southeast Nigeria. International Journal of Analytical Chemistry, 14, 21-28.

Parkes, R. J. \& Taylor, J. (1983). The relationship between fatty acid distribution and bacterial respiratory types in contemporary marine sediments. Estuarine, Coastal and Shelf Science, 16, 173-174. http://dx.doi.org/10.1016/0272-7714(83)90139-7

Parrish, C. C., Abrajano, T. A., Budge, S. M., Helleur, R. G., Hudson, E. D., Pulchan, K., \& Ramos, C. (2000). Lipid and phenolic biomarkers in marine ecosystems: Analysis and Applications. The Handbook of Environmental Chemistry, 5, 194- 223.

Rushdi, A. I., Kassim, T. A., \& Simoneit, B. R. T. (2009). Organic tracers in sediment from the coastal zone of Ras Abu el-Darag. Environmental Geology, 58, 1675-1687.

Saliot, A., Mejanelle, L., Scribe, P., Fillaux, J., Pepe, C., Jabaud, A., \& Dagaut, J. (2001). Particulate organic carbon, sterols, fatty acids and pigments in the Amazon Rivers system. Biogeochemistry, 53, 79-103. http://dx.doi.org/10.1023/A:1010754022594

Seguel, C. G., Mudge, S. M., Salgado, C., \& Toledo, M. (2001). Tracing sewage in the marine environment: Altered Signatures in Conception Bay, Chile. Water Research, 17, 4166-4174. http://dx.doi.org/10.1016/S0043-1354(01)00146-4

Shi, W., Sun, M. Y., Molina, M., \& Hodson, R. E. (2001). Variability in the distribution of lipid biomarkers and their molecular isotopic composition in Altamaha estuarine sediments: Implications for the relative contribution of organic matter from various sources. Organic Geochemistry, 32, 453-467. http://dx.doi.org/10.1016/S0146-6380(00)00189-3

Sun, M. Y., Wakeham, S. G., \& Lee, C. (1997). Rates and mechanisms offatty acid degradation in oxic and anoxic coastal marine sediments of Long Island Sound, New York, USA. Geochimica et Cosmochica Acta, 61, 341-355. http://dx.doi.org/10.1016/S0016-7037(96)00315-8

Tyson, R. V. (2001). Sedimentation rate, dilution, preservation and total organic carbon: some results of a modelling study. Organic Geochemistry, 32, 333-339. http://dx.doi.org/10.1016/S0146-6380(00)00161-3

Unlu, S., \& Alpar, B. (2006). Distribution and sources of hydrocarbons in surface sediments of Gemlik Bay (Marmara Sea, Turkey). Chemosphere, 64, 764-777. http://dx.doi.org/10.1016/j.chemosphere.2005.10.064

Vogel, A. I. (1978). Textbook of Practical Organic Chemistry, p.1371. Longman.

Volkman, J. K., Barrett, S. M., Blackburn, S. I., Mansour, M. P., Sikes, E. L., \& Gelin, F. (1998). Microalgal biomarkers: a review of recent research developments. Organic Geochemistry, 29, 1163-1179. http://dx.doi.org/10.1016/S0146-6380(98)00062-X

Wakeham, S. G. (1999). Monocarboxylic, dicarboxylic and hydroxyacids released by sequential treatments of suspended particles and sediments of the Black Sea. Organic Geochemistry, 30, 1059-1074. http://dx.doi.org/10.1016/S0146-6380(99)00084-4

Xiaoxialu, S., \& Lifeng, N. (2006). Sources and preservation of organic matter in recent sediment from the Changjiang (Jangtse River) Estuary, China. Scientia Marina, 70, 47-58.

Zimmerman, A. R., \& Canuel, E. A. (2001). Bulk organic matter and lipid biomarker composition of Chesapeake Bay surficial sediments as indicators of environmental processes. Estuarine, Coastal and Shelf Science, 53, 819-341. http://dx.doi.org/10.1006/ecss.2001.0815 